Southern Illinois University Carbondale

OpenSIUC

Articles

Morris Library

2007

\title{
Subject Access Points in the MARC Record and Archival Finding Aid: Enough or Too Many?
}

Elizabeth J. Cox

Southern Illinois University Carbondale, bcox@lib.siu.edu

Leslie Czechowski

University of Pittsburgh Health Science Library, lczech@pitt.edu

Follow this and additional works at: http://opensiuc.lib.siu.edu/morris_articles

Part of the Library and Information Science Commons

Published in: Journal of Archival Organization, vol. 5, no. 4 (2007): pp. 51-59.

\section{Recommended Citation}

Cox, Elizabeth J. and Czechowski, Leslie. "Subject Access Points in the MARC Record and Archival Finding Aid: Enough or Too Many?." (Jan 2007).

This Article is brought to you for free and open access by the Morris Library at OpenSIUC. It has been accepted for inclusion in Articles by an authorized administrator of OpenSIUC. For more information, please contact opensiuc@lib.siu.edu. 
Subject Access Points in the MARC Record and Archival Finding Aid: Enough or Too Many?

\author{
Elizabeth Cox \\ Leslie Czechowski
}

\begin{abstract}
In this research project the authors set out to discover the current practice in both the archival and cataloging worlds for usage of access points in descriptive records and to learn how archival descriptive practices fit into long-established library cataloging procedures and practices. A sample of archival finding aids and MARC records at 123 Association of Research Libraries (ARL) institutions were examined to determine if finding aids and catalog records had the same or similar number of access points. The research also provided additional data regarding description of archival materials in these libraries.
\end{abstract}

\title{
KEYWORDS. Archival description, archival finding aids, MARC records, subject headings, subject access points, descriptive cataloging
}

Envision this scenario: An archivist takes a new position in a newly-established archives unit at a university that has not previously provided access to archival collections via MARC records. He has had experience working in both a small college archives and in a major university with a large archival staff including a specialized cataloger. As the archivist begins to advance the discussion on how information in the finding aid will be formatted in the MARC record, he realizes that the head of cataloging is not entirely convinced of the archivist's notions about the "proper" way to formulate the MARC record, especially with regard to subject headings. The head of cataloging points out that the Library of Congress states that a maximum of six subject headings is generally considered appropriate. ${ }^{1}$ But the first finding aid created by the archivist has nineteen access points. What evidence can the archivist give to the cataloger to demonstrate

Elizabeth Cox, , MA in Library Science, is Special Formats Cataloger, Southern Illinois University Carbondale, Morris Library Mailcode 6632, 605 Agriculture Dr., Carbondale, IL 62901 (E-mail: bcox@ lib.siu.edu).

Leslie Czechowski, MA, MLIS, is Head of Collection Services, University of Pittsburgh Health Science Library | System, 200 Scaife Hall, 3550 Terrace Street, Pittsburgh, PA 15261 (E-mail: lczech@ @itt.edu). 
sound archival guidelines or best practices to support inclusion of all nineteen access points in the MARC record ${ }^{2}$ We found nothing in the archival literature that could provide guidance to advance what this archivist needed to persuade the cataloger.

\section{STATEMENT OF THE PROBLEM}

This article examines the current state of subject access points pertaining to finding aids and related MARC formatting. It is intended for archivists and catalogers in institutions that have not yet implemented a broad scale descriptive program for archival and manuscript materials. Our research goal was to learn the current state of professional practice in the archival and cataloging worlds regarding the number of access points used in MARC records for finding aids. In the process we also retrieved information on current archival descriptive practices as well as on how finding aids and MARC records relate to each other. This article focuses on one small portion of the greater body of work on archival description, that which pertains to the number of subject headings used in MARC records.

\section{Literature Review}

Since the publication of Archives, Personal Papers, and Manuscripts (APPM) in 1989, the archival profession has come to accept MARC as a "basic component" in a system of descriptive

practice. ${ }^{3}$ The literature on descriptive finding aids includes discussions of MARC, not as an option for archival description, but as a given, regardless of the authors' opinions about its usefulness. We accept that the archival descriptive process should consist of a finding aid that is available on the Web and via a MARC record. We expect that these descriptive tools will follow 
established guidelines and standards, that access points will adhere to accepted thesauri, ${ }^{4}$ and that the MARC record will be loaded into union catalogs such as OCLC.

The history of archival description is adequately provided in previously published articles such as the excellent discussion by Claire Gabriel ${ }^{5}$ and others cited below. The literature on subject access, however, demonstrates that there is no discussion regarding the relationship between the numbers of access points in a finding aid and its related MARC record.

Subject analysis has been discussed in the archival literature before the use of MARC, indicating the archivist's belief in the vital need for access points in archival description. In 1982, Mary Jo Pugh noted that "current practice relies too heavily on the subject knowledge and memory of the individual archivist."6 Avra Michelson reported a disappointing result regarding archivists' descriptive skills, but indicated that the "greater number of access points created for archival and manuscript collections...significantly affects retrieval." She found that the archivists in her study supplied an average of thirteen index terms derived from the finding aid and said that "archival records describe heterogeneous collections that require many more index terms than those used to describe monographs." ${ }^{, 7}$ Archivists were discussing the differences between archival and library subject analysis even before APPM was published.

In his preface to $A P P M$, Steven Hensen states that the "theory and application of subject cataloging to archival description is beyond the scope of this manual." ${ }^{\text {}}$ He guides archivists to the Library of Congress Subject Headings (LCSH) and the Library of Congress Subject Cataloging Manual. They are useful documents, but do not specifically address archival description. In each edition of her book on $L C S H$, Lois Mai Chan evaluates Library of Congress subjects in a thorough and analytical manner. She asserts that the depth of cataloging may vary from "summarization" to "exhaustive or in-depth indexing." 9 The latter type aims to "enumerate 
all its significant concepts or aspects, or to represent individual component parts of the work," a good description of many types of archival cataloging. ${ }^{10}$ She provides no guidance, however, concerning the numbers of and relationships between archival index terms and library subject headings.

Fredric M. Miller in Arranging and Describing Archives and Manuscripts ${ }^{11}$ provides a thorough, reasoned explanation of the value of standardizing terminology in archival description. But APPM had been published just the previous year, and Miller appeared to be trying to exhort the profession to adopt MARC and library standards. He did not discuss numbers of access points nor demonstrate the relationship between the finding aid and MARC record.

Kathleen D. Roe's Arranging \& Describing Archives and Manuscripts fifteen years later contains a useful section on describing the informational contents of collections. ${ }^{12}$ She writes that unlike library catalog records, "for which access points are a standard component, archival finding aids vary in providing an index or set of terms to assist users in locating information."13 Roe states that providing access points is crucial, but believes that the "specific techniques for subject analysis, selection of terminology, and use of controlled vocabularies are beyond the scope of this manual."14

Three articles come close to defining the relationship between subject access in the MARC record and in the finding aid as well as discussing the numbers of access points in archival descriptive documents. Barbara M. Allchin's master's paper from the University of North Carolina at Chapel Hill compares subject access in seven manuscript collections. She found that the size of the collection did not seem to have "any effect on the number of access points assigned to the collection." The seven collections averaged seventeen access points (from a minimum of eleven to a maximum of twenty-six). ${ }^{15}$ Two of the collections had more subject 
headings in the MARC record than in the finding aid. ${ }^{16}$ She drew no conclusions relating to the numbers of access points in the finding aid versus the MARC record.

Richard P. Smiraglia notes that "it is possible that exhaustive subject indexing can be provided not in the catalog, but rather in the finding aids, ${ }^{, 17}$ a statement somewhat in conflict to Allchin's findings concerning subject analysis in practice. Another UNC master's paper by Rita L. H. Czeck provides results that more directly address our concerns. ${ }^{18}$ She examined twenty finding aids from Berkeley and analyzed access points in the finding aids and related MARC records in great detail. She found that all types of access points were represented, if only minimally, in the MARC record. "The level of representation varies, however, depending on subject category and section of the finding aid....Since the purpose of a MARC record is to represent the most important information from a finding aid, it is expected that not all of the terms would be represented." ${ }^{\prime 19}$ She, then, found that the MARC record, as a surrogate for the finding aid, did contain fewer access points than the finding aid.

Describing Archives: A Content Standard (DACS), was introduced in 2004 to replace APPM. In her preface Kris Kiesling states:

While $A P P M$ was a content standard intended specifically for the creation of catalog records, DACS can be used to create any type or level of description of archival and manuscript materials, including catalog records and full finding aids. ${ }^{20}$

DACS codifies the use of MARC and finding aids as archival descriptive tools and, in contrast to APPM, it does address access points, recommending standards and categorizing the headings. ${ }^{21}$ However, DACS does not make any recommendations about the extent of subject access, that is, how many subject headings may be adequate for a collection, nor does it recommend that the finding aid and MARC record should have the same access points, nor that the MARC record 
contain fewer subject headings. However, in three of the four examples given in Appendix D, ${ }^{22}$ the MARC records and EAD finding aids have the same number of access points, ranging from seven to twenty-one. In the fourth example, "The Herndon-Weik collection of Lincolniana" at the Library of Congress, the finding aid has more access points than the MARC record, apparantly only to save space in the book. The actual online MARC record includes exactly the same fifty-five subject headings as the online finding aid.

However, four examples, even from the new content standard, DACS, did not assure us that it is correct descriptive practice to have the same number of subject headings in the MARC record as there are access points in the finding aid.

\section{Methodology}

The goal of our research was to learn what is the current practice in the archival and cataloging worlds regarding the number of access points used in MARC records for finding aids. In the process we also retrieved information on current archival descriptive practices and how the finding aid and MARC record relate to each other.

Member libraries of the Association of Research Libraries (ARL) ${ }^{23}$ comprise our sample $(N$ = 123). Web sites for each library were scanned to find the archives and/or special collections pages and from there, the online finding aids and MARC records. Purposive sampling was used to select certain collections from which to gather our data, as many sites had numerous online finding aids. Where possible, we chose the $1^{\text {st }}, 10^{\text {th }}, 20^{\text {th }}$, etc., collection to look at for our database. We limited our list to five collections per institution unless there were multiple, distinct repositories at one university and then we sampled a few finding aids from each archival unit. 


\section{Results}

Of the 123 ARL libraries, 27 (22\%) either did not have any finding aids online, we were unable to locate the finding aids, or we were unable to locate the institution's special collections or archives Web pages. Of the remaining 96 libraries, 37 have online finding aids with no access points. $^{24}$

We viewed 271 collection finding aids online from the remaining 59 ARL libraries (see Figure 1). 169 (62\%) have access points in both the finding aids and the MARC records; 46 (17\%) have access points in the online finding aid and either none in the MARC record or no MARC record was found; $29(11 \%)$ have access points in the MARC record and none in the finding aid; and $27(10 \%)$ have no access points in the online finding aid and either none in the MARC record or no MARC record was found.

\section{FIGURE 1}

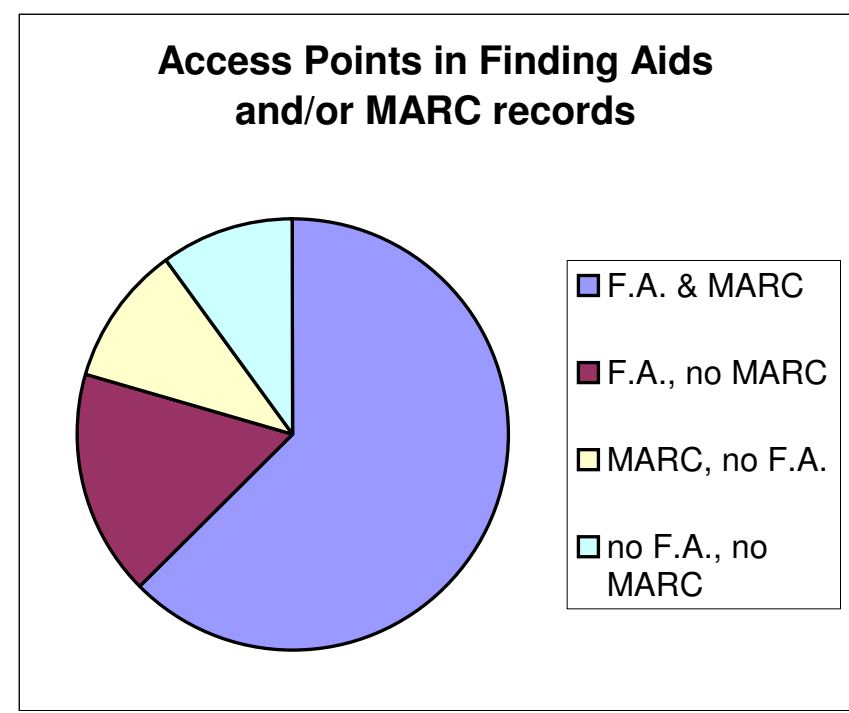

$\begin{array}{lc}\text { F.A. \& MARC } & 169 \\ \text { F.A., no MARC } & 46 \\ \text { MARC, no F.A. } & 29 \\ \text { no F.A., no MARC } & 27\end{array}$


Through our research we determined that the only current rules or guidelines for the usage of access points are those that the Library of Congress supplies - that six heading are generally appropriate but that no more than ten subject headings should be used ${ }^{25}$ Our scan of ARL libraries shows that many librarians are choosing not to follow these guidelines (see Figure 2). Of the selected items viewed, 118 MARC records contain over eight access points, while 76 have eight or less.

\section{FIGURE 2}

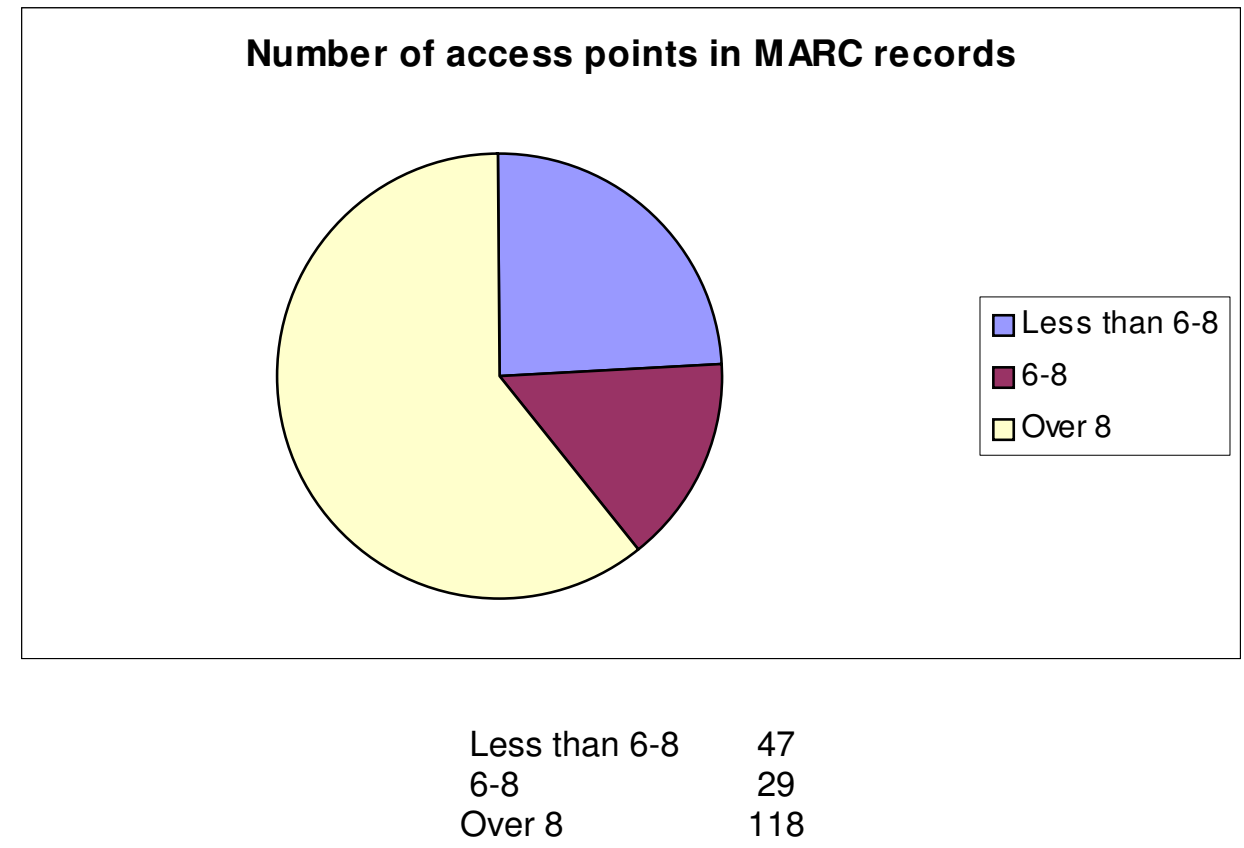

We also looked at whether libraries chose to use the same number of access points in both their finding aids and MARC records. Our review shows that the decisions are inconsistent, even within the same institution. Seventy-five collections had more access points in the finding aid, 64 had more in the MARC record, and 57 had exactly the same number.

Although the main focus of our research was not on metadata, we did take note of those libraries that were using some form of metadata. Of the 96 ARL libraries with online finding aids, we determined that 47 libraries (49\%) are using EAD, according to information available 
on their Web site. 15 (16\%) are using some other form of metadata. The remaining 34 libraries (35\%) are not using any type of metadata scheme.

\section{Discussion}

After analyzing our results, we determined that assumptions cannot be made about the policies or procedures employed by ARL libraries with regard to subject headings in MARC records for archival collections. We did discover that libraries are not adhering to the "six or less subject headings" rule for MARC records; accepted practice appears to be to use what is needed, regardless of the number. We found seven different records that used 50 or more access points.

We also discovered that there is a wide range of practice, not only within the ARL libraries as a group, but also within individual institutions. For example, one collection in a library will have finding aids fully cataloged in EAD as well as in a MARC record, whereas a different collection in the same institution will only have a simple text finding aid available with no access points and no MARC record.

There is also a variance in formats of archival description. Some of this may be due to the changes with EAD and DACS. For example, when we began our research in December 2005, one library did not have its finding aids available in EAD; five months later, they were available in EAD. Some institutions have some finding aids available in PDF and in EAD, others in EAD and HTML.

One item in particular jumped out at us after reviewing this data. Why do some libraries have access points in the MARC records but not in the finding aids? Although many online catalogs are fully accessible to any library or Internet user, most search engines will find keywords, including subject terms, in finding aids more quickly than in MARC records. 


\section{CONCLUSION}

A number of potential areas of future study surfaced during our research. For example, how many access points are enough to produce a synthetic surrogate reflective of the finding aid itself? Another topic might be to directly contact some or all of the ARL libraries with follow-up questions: Why do your online finding aids not include index terms? Why are some in PDF and some in EAD?

This study brought to light the wide variances in archival descriptive practice and the ongoing changes as archivists and catalogers adopt new standards of practice. Our results show that currently there are no guidelines to help archivists and catalogers determine access point usage. Perhaps this should be a topic for further discussion by these communities and their guiding organizations.

This study provides an interesting snapshot of archival description at this point in time. Two years from now, this material will look very different.

\section{NOTES}

1. Library of Congress, Subject Cataloging Manual: Subject Headings. 5th ed. (Washington, D.C.: Library of Congress, 2000), H180, 2.

2. We recognize that currently OCLC limits the number of fields per record

3. Michael J Fox, "Descriptive Cataloging for Archival Materials," In Describing Archival Materials: The Use of the MARC AMC Format. Ed. by Richard P. Smiraglia. (New York: Haworth Press, 1990), 21.

4. These include the recent book: Describing Archives: A Content Standard (DACS); standards for encoded archival description (EAD); Library of Congress Subject Headings (LCSH); Library of Congress Name Authority Records (NARs); Art \& Architecture Thesaurus (AAT).

5. Claire Gabriel, "Subject Access to Archives and Manuscript Collections: An Historical Overview." Journal of Archival Organization 1, no. 4 (2002): 53-63. 
6. Mary Jo Pugh, "The Illusion of Omniscience: Subject Access and the Reference Librarian.” American Archivist 45 (Winter 1982): 38.

7. Avra Michelson, "Description and Reference in the Age of Automation." In American Archival Studies: Readings in Theory and Practice. Ed. by Randall C. Jimerson. (Chicago: Society of American Archivists, 2000), 369.

8. Steven L. Hensen, Archives, Personal Papers, and Manuscripts: A Cataloging Manual for Archival Repositories, Historical Societies, and Manuscript Libraries. 2nd ed. (Chicago: Society of American Archivists, 1989), viii.

9. Lois Mai Chan, Library of Congress Subject Headings: Principles and Applications. 4th ed. Westport, CT: Libraries Unlimited, 2005, 173.

10. Ibid.

11. Fredric M. Miller, Arranging and Describing Archives and Manuscripts. (Chicago: Society of American Archivists), 1990.

12. Kathleen D. Roe, Arranging \& Describing Archives \& Manuscripts. (Chicago: Society of American Archivists, 2005), xiii. Roe states in the footnote that her book "replaces" Miller's.

13. Ibid., 82.

14. Ibid., 83.

15. Barbara M. Allchin, "Subject Access to Archival Collections: A Comparison of Online Finding Aids and MARC Records for Manuscript Collections in the Southern Historical Collection" (MSLS thesis, University of North Carolina, 1995), 32.

16. Ibid., 34.

17. Richard P. Smiraglia, "Subject Access to Archival Materials Using LCSH.” In Describing Archival Materials: The use of the MARC AMC Format. Ed. by Richard P. Smiraglia. (New York: Haworth Press, 1990), 69. 18. Rita Leanne Hammons Czeck, "A Comparison of Archival MARC Records and Full-text Finding Aids in the Context of End-user Subject Access to Archival Collections. (MSLS thesis, University of North Carolina, 1997).

19. Ibid., 21.

20. Describing Archives: A Content Standard. (Chicago: Society of American Archivists, 2004), vii. 
21. Ibid., xviii-xxi.

22. Ibid., 225-268.

23. Association of Research Libraries. Member Libraries, Member Links. http://www.arl.org/members.html

24. Web sites were accessed between December 2005 and July 2006. Results are based on information gathered during that time.

25. Library of Congress. Subject Cataloging Manual: Subject Headings. 5th ed. (Washington, D.C.: Library of Congress, 2000), H180, 2. 